\title{
97. Fate of Zona Reticularis in Adrenal Cortex of Castrated Male Mice.
}

By Kiyoshi TAKEWAKI.

Zoological Institute, Faculty of Science, Tokyo Imperial University.

(Comm. by N. YATSU, M.I.A., Nov. 12, 1937.)

It is now well established that the zona reticularis of the adrenal cortex of male mice disappears by the onset of puberty but, if castration is performed prior to sexual maturity, the zona reticularis does not degenerate but continues to enlarge until it occupies in section about one-third or more of the thickness of the cortex (Masui and Tamura, 1924, 1926 ; Masui, 1926 ; Howard-Miller, 1927, 1930 ; Deanesly, 1928 ; Kukita, 1930 et al). But the fate of the zone in the castrated male mice has not yet been definitely known.

Kukita $(1930)^{1)}$ reported that the zona reticularis was well maintained and did not show any sign of degeneration during nine months after castration. Howard-Miller $(1930)^{2)}$ found that the adrenals of nine mice castrated at 12 to 28 days of age and sacrificed at 231 to 266 days contained only remnants of the zone as either spongy reticular tissue or as narrow compact band of small flattened cells occupying the inner part of the cortex. She also castrated two mice at 24 days of age and studied the left adrenals at 160 days and the right ones at 199 days and found that in both cases younger glands contained a zone which had not undergone degeneration, while the older glands showed a thin zone of small compact cells and some spongy reticular tissue. From this, Howard-Miller concluded that castration does not prevent the ultimate degeneration of the zone, although it brings about the initial growth of the zone.

I have studied the adrenals of eight mice castrated when a month old and offered about 9 to 18 months after the operation. The findings are summarized in the following table (Table 1).

TABLE 1.

\begin{tabular}{|c|c|c|}
\hline Mouse & $\begin{array}{c}\text { Interval between castration } \\
\text { and autopsy }\end{array}$ & Zona reticularis \\
\hline $\mathbf{A}$ & 263 days & $\begin{array}{l}\text { well developed, without any sign of } \\
\text { degeneration. }\end{array}$ \\
\hline B & 273 & $\begin{array}{l}\text { developed but cells in outer half hyper- } \\
\text { trophied (fig. 1). }\end{array}$ \\
\hline $\mathrm{C}$ & 325 & $\begin{array}{l}\text { developed but inner part adenomatous } \\
\text { (fig. 2). }\end{array}$ \\
\hline $\mathrm{D}$ & 325 & $\begin{array}{l}\text { developed but inner part adenoma- } \\
\text { tous. }\end{array}$ \\
\hline $\mathrm{E}$ & 356 & $\begin{array}{l}\text { well developed, without any sign of } \\
\text { degeneration. }\end{array}$ \\
\hline
\end{tabular}

1) Kukita, G. 1930 Jikken Igaku Zasshi, vol. 14, pp, 38-69.

2) Howard-Miller, E. 1930 Anat. Rec,, vol. 46, pp. 93-104. 


\begin{tabular}{c|c|c}
\hline Mouse & $\begin{array}{c}\text { Interval between castration } \\
\text { and autopsy }\end{array}$ & Zona reticularis \\
\hline F & 468 days & $\begin{array}{c}\text { developed but in part transformed into } \\
\text { spongy tissue (fig. 3). } \\
\text { well developed without any sign of } \\
\text { degeneration (fig. 4). } \\
\text { developed but in part transformed into } \\
\text { spongy tissue. }\end{array}$ \\
\hline H & 511 & 546
\end{tabular}

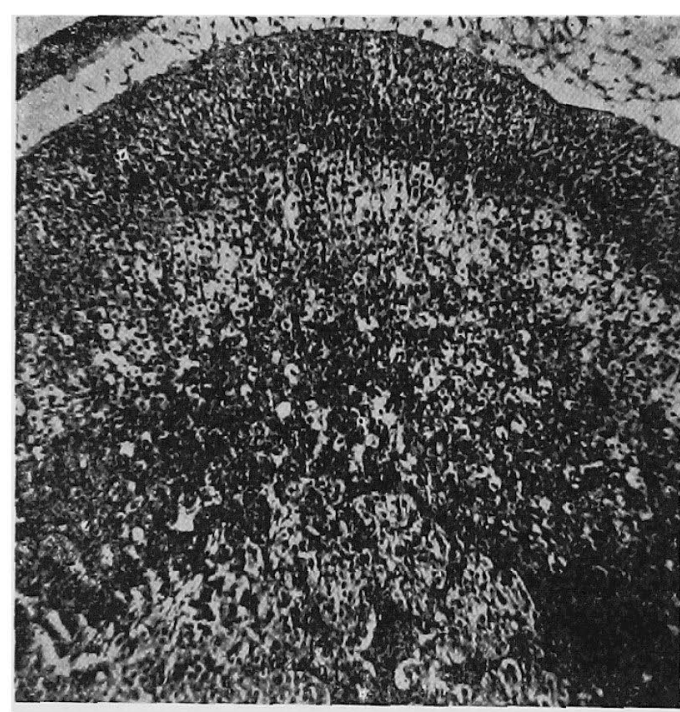

Fig. 1. Adrenal of male 273 days after castration. Cells of outer half of zona reticularis have hypertrophied. $\times 65$

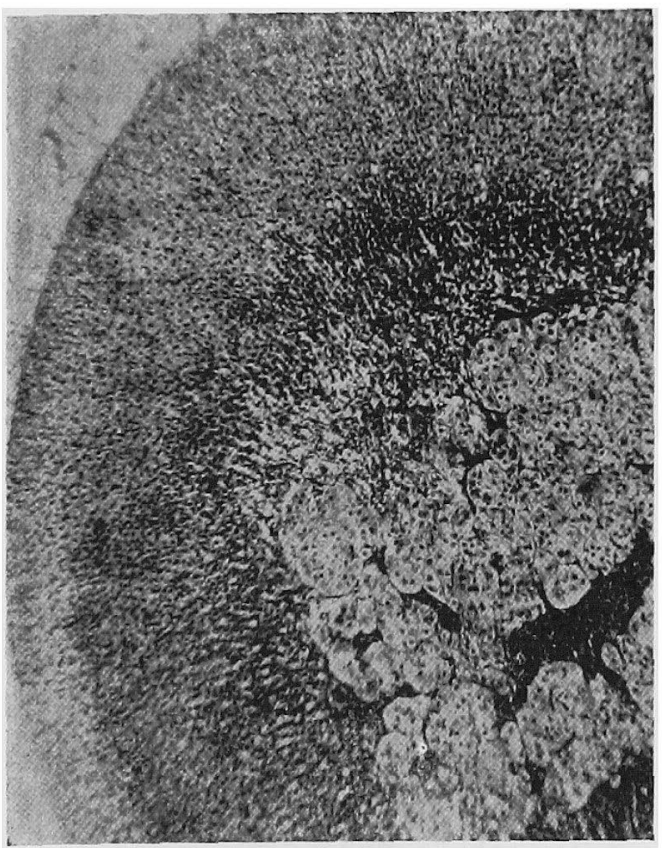

Fig. 3. Adrenal of male 468 days after castration. Part of zona reticularis has been transformed into spongy tissue. $\times 65$

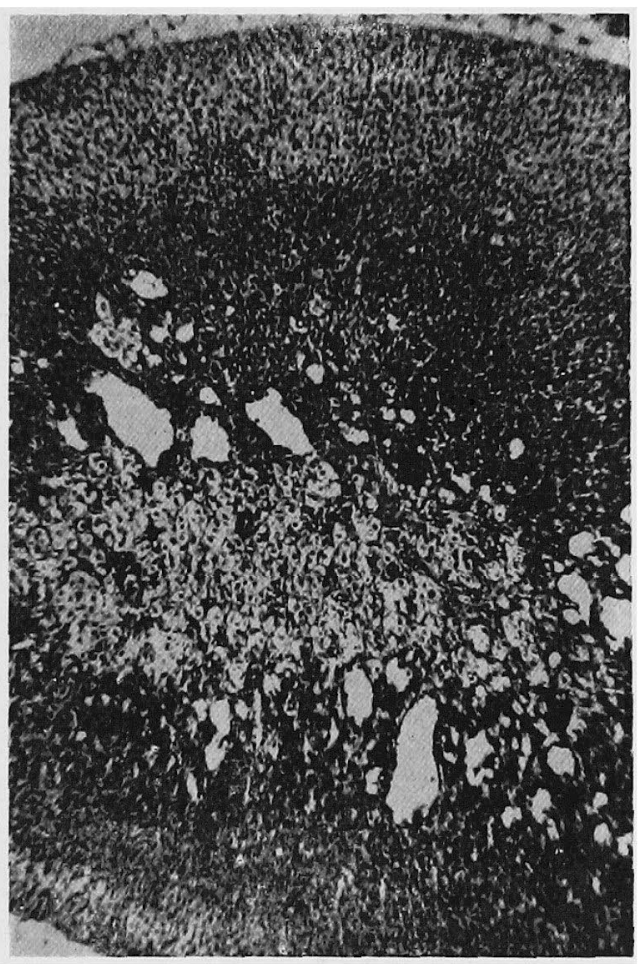

Fig. 2. Adrenal of male 325 days after castration. Inner part of zona reticularis has become adenomatous. $\times 65$

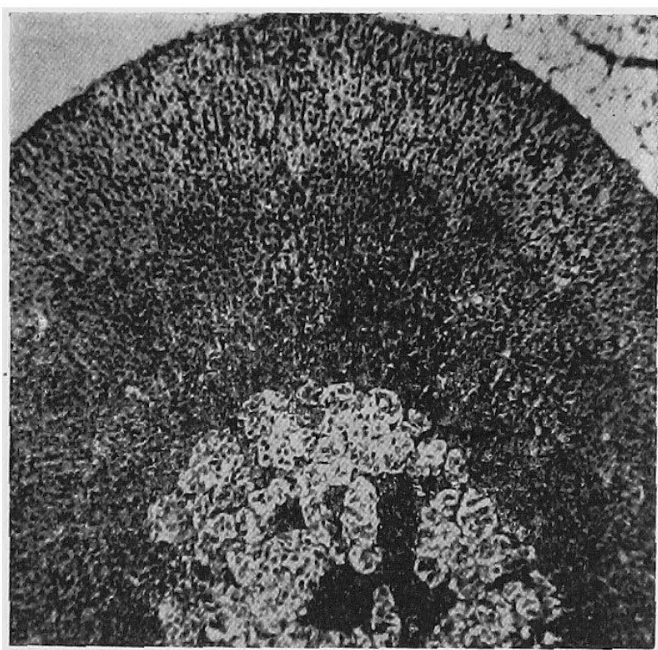

Fig. 4. Adrenal of male 511 days after castration. Zona reticularis has been well developed. $\times 65$ 
All the animals except one (mouse G) were apparently in good health when autopsies were performed. The mouse $G$ was showing some signs of senility such as paucity of hair and weakness of legs.

It should be concluded that the zona reticularis stays at least under certain circumstances for a year and a half or perhaps longer after castration. But various kinds of degenerative phenomena take place in the zone of the males which have been long castrated. 